\title{
A MODEL OF WORK-FAMILY DYNAMICS OF HOTEL MANAGERS
}

\author{
Rebecca Harris Mulvaney \\ ICF Consulting, USA \\ John W. O'Neill \\ Jeanette N. Cleveland \\ Ann C. Crouter
}

\author{
The Pennsylvania State University, USA
}

\begin{abstract}
The tourism industry is well known as one where operating managers have had to make sacrifices in their family and personal lives. This article reviews what is known about the work-family interface in relation to hotel managers in an effort to identify ways to gain a strategic advantage in this competitive sector. By integrating research from several disciplines, this article presents a heuristic framework delineating organizational level inputs to workfamily relationships for tourism managers. It examines organizational-, individual-, and family-level outcomes of the interface, as well as the processes linking these components and moderators thought to impact these relationships. Conclusions focus on innovative practices implemented to address work-family concerns. Keywords: work-family linkages, policies, hotel sector, human resources. (c) 2006 Elsevier Ltd. All rights reserved.
\end{abstract}

Résumé: Un modèle de la dynamique travail-famille des directeurs d'hôtel. Il est bien connu que le tourisme est une industrie où les directeurs d'opération sont obligés de faire de grands sacrifices dans leur vie familiale et personnelle. Cet article fait le point sur ce que l'on sait de l'interface travail-famille chez les directeurs d'hôtel afin d'identifier des façons de gagner un avantage stratégique dans ce secteur compétitif. En intégrant des recherches de plusieurs disciplines, l'article présente un cadre heuristique représentant des apports organisationnels aux relations travail-famille pour les directeurs de tourisme. On examine les résultats aux niveaux organisationnel, individuel et familial de l'interface aussi bien que les processus qui relient ces éléments et les facteurs qui semblent avoir un effet sur ces relations. Les conclusions portent surtout sur des pratiques innovatrices pour aborder les questions de travail-famille. Mots-clés: liens travail-famille, politiques, secteur hôtelier, ressources humaines. (C) 2006 Elsevier Ltd. All rights reserved.

\section{INTRODUCTION}

The recent recovery in business tourism after September 11th (O’Neill 2005) has forced hotel and other types of tourism companies to critically examine operations and performance and to reassess strategies for gaining competitive advantage in this economic sector. Given

Rebecca Harris Mulvaney is an industrial/organizational psychologist with ICF Consulting (9300 Lee Highway, Fairfax VA 22031, USA. Email <rmulvaney@icfconsulting.com>). Other co-authors are all at Penn State University. John O'Neill is Assistant Professor in the School of Hospitality Management. Jeanette Cleveland is Professor of Industrial and Organizational Psychology. Ann Crouter is Professor of Human Development and Director of the Center for Work and Family Research. 
the challenges the industry has historically faced with work-family conflict (Dermody and Holloway 1998; Stalcup and Pearson 2001), tourism companies may be able to achieve strategic advantage by effectively addressing work-family issues. Management jobs in this field are noted for having characteristics known to be detrimental to family life (including long irregular hours, emphasis on face time, and frequent relocation). In fact, Presser (2004) found that lodging management is one of the top ten occupations in the United States with nonstandard work schedules and has the highest percentage of people working varying shifts and weekends.

Researchers and some companies are beginning to attend to how these job characteristics influence employees and their families and what impact employees' work-family concerns are having on the bottom line, but the research is sparse and lacks a guiding framework. Companies can position themselves to attract and retain valued managers, improve performance and customer satisfaction, and reduce common industry-wide problems, such as turnover, by studying the work-family interface.

Because of the size and diversity of the industry, this article focuses specifically on the hotel sector. The goal is to present a heuristic framework of its work-family interface to organize knowledge in this area and to encourage researchers to learn more about unique issues in this population. The research findings presented here provide a sound justification for hotel executives to incorporate work and family concerns in strategies to enhance their company's ability to compete in the marketplace. Although scholars have called for the industry as a whole to address work-family needs of the employees (Dermody and Holloway 1998; Stalcup and Pearson 2001), very few empirical studies have focused on this issue. This article integrates studies generated by researchers in the hospitality area with relevant studies from the wider literature on work and family.

\section{WORK-FAMILY ISSUES IN HOTEL COMPANIES}

As shown in Figure 1, in the proposed framework, the organizational context, the unique work environment, influences hotel company, individual employee, and employee family outcomes via work-life conflict and facilitation. The heuristic framework introduced describes the processes that comprise the work and family interface. These include work-family conflict, defined as occurring when "participation in the work (family) role is made more difficult by virtue of participation in the family (work) role" (Greenhaus and Beutell 1985:77). They also include work-family facilitation, defined as "the extent to which participation at work (or home) is made easier by virtue of the experiences, skills, and opportunities gained or developed at home (or work)" (Frone 2003:145). The framework conceptualizes the organizational context as encompassing the extent to which a hotel company's culture is family-friendly, or conversely, reflects several detrimental industrylevel norms. The model incorporates potential moderators of the link 


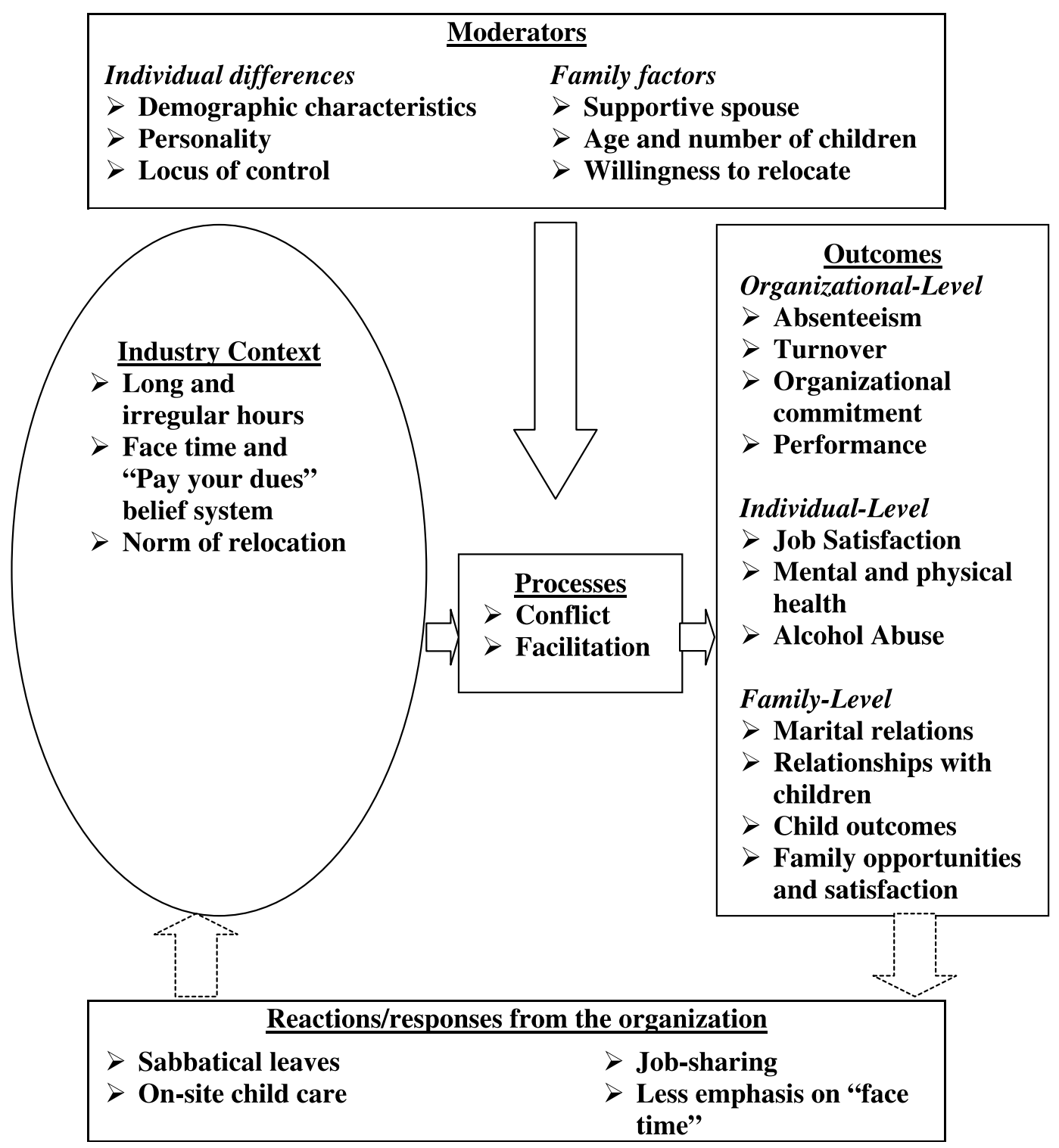

Figure 1. A Proposed Model of Work-Family Issues for Hotel Managers

between organizational factors and work-life outcomes, specifically individual differences in employees' personal characteristics and variations in family circumstances. Outcomes are discussed at the organizational, individual, and family levels. Finally, the framework considers how some hotels have responded to work and family issues and how these responses may affect the organizational context. The article is structured around specific propositions regarding the complex relationships described in the model. In each section, the propositions are elaborated by making reference to relevant research and pointing to new directions for future investigation.

\section{Processes}

Researchers agree that the work and family interface is a highly complex set of relationships, and there has been much debate regarding 
the underlying structure of these relationships. A basic understanding of this structure is crucial to set the stage for developing or implementing effective work-life policies.

General Processes. A review by Kossek and Ozeki (1998) identified three models to describe the links between work and family. The first is the spillover model, which posits that attitudes and behaviors will carry over or generalize from one's work life to one's family life (such as, if employees are feeling satisfied with work, they should also be satisfied with their life outside of work), and vice versa (Leiter and Durup 1996). The "spillover model" has been used to discuss the transfer of positive attitudes and behaviors (positive spillover), such as satisfaction, as well as negative attitudes and behaviors (negative spillover), such as stress. In contrast, in the "compensation model" there is a negative relationship between attitudes and behaviors in the work and family domains (Greenglass and Burke 1988). If employees are dissatisfied with their jobs, for example, they may devote more time and energy to their family to compensate for the lack of rewards in their jobs. Further, the segmentation model operates under the assumption that the work and family domains are unrelated because people are able to compartmentalize their roles (Lambert 1990).

Conflict. Conflict arises when participation in one role is made more difficult by virtue of participation in another role. This can occur via spillover, as noted above, or via a process known as resource drain (Frone 2003). This model is similar to the compensation one in that it argues that there is a negative relationship between work and family, but here the reasoning is that a person has a finite store of resources (time, energy). Research in this area has been dominated by the idea that separate roles compete for limited amounts of time, energy, and psychological resources. The strain that this competition creates is thought to result in a variety of negative consequences both at work and at home (Barnett 1996; Perry-Jenkins, Repetti and Crouter 2000). The spillover and resource drain models are not necessarily at odds; both likely play a role in the relationship between work in the hotel business and a manager's life outside of work. Indeed, this article describes research that demonstrates that both processes play roles in shaping the relationship between work in the sector and life off the job.

Facilitation. One area of research in the work and family domain that has received little attention is the concept of facilitation. Frone (2003) described work-family facilitation as the extent to which participation at home is made easier by virtue of the experiences, skills, and opportunities gained or developed at work or vice versa. For example, using self-report data from employees in a manufacturing plant, Crouter (1984a) presented evidence that employees who engaged in participative, semi-autonomous work teams acquired skills that they in turn generalized to their family and community lives. Similar to conflict, facilitation is bidirectional in nature. The manufacturing employees 
Crouter (1984b) studied reported that skills acquired from raising families facilitated their performance on the job as well. As with conflict, the focus of this article is on facilitation that originates in the workplace.

Each of these approaches to conflict has different implications for organizations. For example, the segmentation model holds that work and family are completely unrelated and implies that an organization need not concern itself with employees' family lives. In contrast, the spillover model, for which there is the most empirical support, implies that it is in the organization's best interest to assist employees with work-family concerns because, left unaddressed, they may interfere with employees' productivity and effectiveness at work. While research tends to favor the spillover model, many organizations continue to operate as if they endorse the segmentation one (Milliken, Martins and Morgan 1998). The model presented here reflects elements of the spillover (both positive and negative) and the resource drain models. The propositions will address both conflict and facilitation.

\section{Antecedents Linking Work and Family Domains}

Factors that affect the work and family relationship at two levels are to be described: the industry context and the organizational variation within it. The former plays a crucial role in directly or indirectly shaping the relationships among employees, their jobs, and their families. The sector has several specific cultural norms or expectations regarding behavior or attitude that are particularly relevant to employees' work-family interface, including expectations regarding long and irregular hours, face time and "paying your dues" (Eder and Lundberg 1990; Munck 2001), and relocation (Kennedy and Fulford 1999), especially among hotel managers.

While these characteristics are common in this business as a whole, they are not necessarily present to the same degree across companies. For the purposes of this discussion, organizational context is defined as the extent to which a hotel organization reflects characteristics described above. It also encompasses the hotel's work-family culture, or "the shared assumptions, beliefs, and values regarding the extent to which an organization supports and values the integration of employees' work and family lives" (Thompson, Beauvais and Lyness 1999: 394). These company-level variations contribute to individual companies having unique environments that may give some companies an advantage over others by impacting such factors as employee recruitment, retention, and general well-being (including health, satisfaction). In the proposed framework, the extent to which a hotel company reflects the common tourism norms of long and irregular hours, face time, and relocation, as well as the family-friendliness of the organizational culture, are features that impact managers at individual, family, and organizational levels directly and indirectly.

Many hotel positions, both managerial and line, require long and irregular hours because hotels are open 24 hours daily. Having too 
few employees present can result in poor guest service, frustrated and overworked employees, and lost sales. Labor scheduling is a particular challenge because managers must balance customer demands, employee work requests, and profitability (Thompson 1998). In large part, because of the demands of being a " $24 / 7$ ' industry, hotel companies often have norms that encourage employees, especially managers, to work as many hours as possible, including weekends and holidays. Indeed, managers in Stalcup and Pearson's (2001) study mentioned long hours and not having enough time to spend with families as a major reason for turnover. Nonstandard, irregular hours have also been well-established as a correlate of lower marital quality and divorce, less time with family, children with more problem behaviors, and increased conflict (Presser 2000, 2004).

Not only are employees often required to keep long and irregular hours, but there is an expectation that employees, especially managers, will be physically present as much as possible, regardless of the actual necessity of being there. Munck called this the "culture of face time" (2001:125). This norm is also reinforced by the widespread norm in the hotel sector that employees must "pay their dues" to get ahead (Eder and Lundberg 1990:367). Organizational expectations regarding how much time employees should spend at work have become a relatively well-established antecedent to work-life conflict (Frone, Yardley and Markel 1997; Thompson et al 1999; Thompson, Thomas and Maier 1992). Crouter, Bumpus, Maguire and McHale (1999), for example, found that the extent to which jobs were characterized by deadlines, demands, and fast pace contributed to role overload (the feeling that there is insufficient time to accomplish everything one needs to accomplish), which in turn was linked to higher levels of parent-child conflict. If career dedication and employee value are measured by hours present at the office, employees will be reluctant to leave early or take time off for family reasons (Thompson et al 1999). In the long run, this may result in turnover, reduced commitment, or lower productivity.

The hotel sector also has a norm of frequent relocation, particularly for managers (Kennedy and Fulford 1999). In a case study of these in a US hotel company, one manager mentioned that she had moved five or six times in ten years, and another added, "You don't turn down a move" (Kennedy and Fulford 1999:66). While relocation is a major part of career advancement in this business, it can contribute to conflict in that it is very disruptive and stressful to families, requiring transitions to new schools, neighborhoods, and employers for working spouses (Lu and Cooper 1990; Martin 1999). In fact, Munton (1992) found that over $50 \%$ of relocators reported high levels of stress up to six months following their move.

Relocation does not necessarily have only negative effects, however. Relocation can offer employees and their families opportunities and resources that can enhance family life, such as a chance for families to experience living in and learning about new cultures. In fact, Brett (1982) compared mobile (non-hotel) male employees with stable ones and found that although the latter and their wives were more satisfied 
with their social relationships, mobile employees and their wives were more satisfied with their lives, families, and marriages. That said, relocation preparation and services, such as real-estate assistance and visits to the area, are key to successful relocations (Eby and Allen 1998; Martin 1999).

The above characteristics are general lifestyle factors that impact an employee's family. Organizations also have a unique culture in terms of how they view employees' lives off the job, referred to here as the family-friendliness of the culture, or the work-family culture. This encompasses shared assumptions, beliefs, and values regarding employees' work-family balance, very important factors in the interface between work and family. Using survey data from 276 managers and professionals, Thompson et al (1999) found that perceptions of a supportive workfamily culture were related to greater use of family-friendly benefits, higher affective commitment to the organization, and lower conflict.

Thompson et al identified three dimensions of work-family culture: managerial support for work-family balance, career consequences associated with utilizing work-family benefits, and organizational time expectations that may interfere with family and other non-work responsibilities. A supportive workplace is essential to the successful implementation of any type of work-family policy, as well as to the general satisfaction and well-being of employees (Galinsky, Bond, and Friedman 1996; Thompson et al 1999). Supervisory support has been found to be an especially important determinant of the effectiveness of family-friendly policies (Thomas and Ganster 1995), in part because a supervisor is seen as a representative for the organization. A company may adopt an innovative, comprehensive set of polices, but a workplace culture that is antagonistic to utilizing them undercuts their effectiveness (Frankel 1998). Another dimension of an organization's work-family culture is the career consequences linked with work-family policies, such as leaves of absence. For example, generally, leaves of absence are associated with fewer subsequent promotions, smaller salary increases, and lower performance ratings (Judiesch and Lyness 1999), especially for men (Allen and Russell 1999). The last of Thompson et al's (1999) dimensions of work-family culture is organizational time expectations, which is very similar to the idea of "paying your dues," (because this factor is so prevalent in this business, it is discussed separately).

The hotel sector is known for demanding long and irregular hours, an expectation of face time for managers, and requiring relocation in order to move up in the ranks, all factors thought to contribute to conflict. Within the sector, however, these characteristics exist in specific companies to varying degrees. Additionally, individual enterprises differ in the extent to which their particular organizational cultures are family-friendly. This article posits that managers in hotel companies requiring long and irregular hours, face time, and relocation will report higher levels of conflict and lower levels of facilitation. Conversely, managers in hotel companies with cultures that are more family-friendly will report lower levels of conflict and higher levels of facilitation than managers working in hotels that are less so. 
Proposition 1a: Hotels with less family-friendly norms and cultures will be associated with manager reports of increased conflict.

Proposition 1b: Hotels with more family-friendly norms and cultures will be associated with manager reports of increased facilitation.

\section{Organizational, Individual and Family Outcomes}

The outcomes included in this heuristic framework are seen at several interrelated levels of analysis, including the organizational, individual, and family.

Organizational Level. Work-family conflict and facilitation impact organizations and employees at several levels. The most widely studied organizational-level outcomes of work and family issues include absenteeism, turnover, and performance. Employees with high levels of conflict are more likely to miss work for family reasons (Kossek and Ozeki 1999). Absenteeism is an especially important concern for the hotel sector because of the complexity of its labor scheduling.

Turnover is one of the most prevalent concerns, which has even been described as having a "turnover culture" (Deery and Shaw 1997:377). Work-to-family conflict is fairly well established as a predictor of intentions to quit a job, as well as actual turnover (Greenhaus, Parasuraman, and Collins 2001; Kirchmeyer and Cohen 1999). If employees experience high levels of work-family conflict, they may move to a job in a company (or industry) they perceive will be associated with less conflict. In fact, Dermody and Holloway (1998) noted that work hours and the resulting work-family conflict were major contributors to these retention problems.

Job performance is the final outcome of the model, a link only beginning to be explored, especially in the hotel sector. There have been a few studies linking family life with job performance. Several have shown work-family conflict to be negatively related to job performance (Aryee 1992; Frone et al 1997), especially among customer service representatives (Netemeyer, Maxam, and Pullig 2005). Conversely, selfreports of work-family facilitation appear to be linked positively with job effort, or how much thought and exertion people put into their work (Wayne, Musisca and Fleeson 2002).

Several studies have found that involvement in non-work roles, such as parenthood or leadership roles in community organizations, is positively related to job performance, particularly organizational (time management, prioritizing) and interpersonal aspects of job performance, which are especially important in a service industry and among managers (Crouter 1984b; Ruderman, Ohlott, Panzer and King 2002). In addition, Harris Mulvaney and Grandey (2004) found that commitment to non-work roles was associated with higher peer ratings of job performance, via skill efficacy, for example. Similarly, Ruderman et al (2002) demonstrated a link between commitment to non-work roles and 360-degree ratings of managerial skills, such as understanding and motivating others. While research in this area is sparse, these 
studies offer preliminary evidence that work-family issues may be associated with employee performance.

Work-family conflict is a known contributor to withdrawal behaviors such as absenteeism and turnover; furthermore, it is thought to detract from job performance, especially its interpersonal aspects, which are critical in a service industry. It is argued here that the positive relationship between conflict and withdrawal behaviors is particularly salient for the hotel sector, where turnover and absenteeism are major concerns. Similarly it is proposed that job performance will be positively associated with facilitation and negatively with conflict, given the emphasis on service required for success in this tourism business.

Proposition 2a: Work-family conflict will be positively related to absenteeism and turnover, and negatively associated with job performance.

Proposition 2b: Work-family facilitation will be positively related to job performance, particularly its interpersonal and organizational aspects.

Individual Level. The work and family interface affects organizations, in large part, through the individual-level outcomes associated with work-family issues. Those most often examined that are relevant to the hotel sector include job satisfaction, organizational commitment, health-related outcomes (depression, cholesterol levels, and general physical health), and high levels of alcohol use. Kossek and Ozeki's (1998) study on the outcomes of work-family conflict underscored that job satisfaction is one of the most widely studied outcomes of conflict and that research has been consistent in demonstrating a fairly strong negative relationship between conflict and job satisfaction, regardless of industry. Job satisfaction is related to intentions to turnover (Hulin 1991). Furthermore, Spinelli and Canavos (2000) found that across surveyed guests and employees at six full-service hotels in four major cities, employee satisfaction and guest satisfaction were significantly and positively linked.

Similarly, there is typically a strong negative association between conflict and organizational commitment (Kossek and Ozeki 1999; Thompson et al 1999). Organizational commitment is defined as "the relative strength of an individual's identification with and involvement in a particular organization" (Mowday, Porter and Steers 1982:27). Conceptually, it is characterized by at least three factors: belief in the organization's goals and values, willingness to exert effort on its behalf, and desire to maintain membership in it. Organizational commitment is a key construct to examine in this model because of its positive association with withdrawal behaviors such as lateness, absenteeism, and turnover (Mathieu and Zajac 1990), all costly factors to hotels.

Also related to lateness and absenteeism, mental and physical health outcomes related to conflict have been widely studied and include higher levels of stress and depression, higher cholesterol levels, and generally poorer levels of self-reported physical health (Frone, Russell, and Barnes 1996; Frone et al 1997; Grandey and Cropanzano 1999). Work-family conflict may be related to higher levels of alcohol use (Frone et al 1996, 1997), particularly in the hotel sector (Corsun and 
Young 1998). Specifically, people who believe in alcohol's capacity to act as a coping mechanism in response to stress in turn are more likely to use this as a coping mechanism and to subsequently have drinking problems (Cooper, Frone, Russell and Mudar 1995). This problem is particularly relevant to the business. Corsun and Young (1998) found evidence of an occupational subculture in the hospitality sector whose norms promote drinking. Their findings indicated that alcohol might be seen as a buffer for work stressors and strains among managers.

The work-family literature has widely examined the impact of conflict on individual outcomes-decrease in job satisfaction, in organizational commitment, and in mental and physical health being among the most common of those outcomes. This article proposes that there will be a negative relationship between reports of conflict and job satisfaction, organization commitment, and mental and physical health. This link should be of particular concern, given these outcomes' relationships with others such as turnover and absenteeism. Furthermore, it is expected that conflict will have a positive relationship with alcohol use, a common problem in the hotel sector (Corsun and Young 1998).

Proposition 3: Work-family conflict will be negatively related to job satisfaction, organizational commitment, and mental and physical health, and it will be positively related to alcohol use.

Family Level. The hotel sector is a major player in what Presser refers to as the "24/7 economy" (2004:83). Aside from the work-related strains and conflicts that tend to occur across industries, a number of positions within hotels require employees to work non-daytime hours. Relocation is also very common. These situations can have serious effects on the family, and can be major contributors to work-family conflict (Lu and Cooper 1990; Martin 1999). Family outcomes presented in this model include marital relations, parent-child relations, child outcomes, and family opportunities.

While very little work-family research has occurred in the hotel context, there is substantial evidence across industries that stress and conflict originating from the workplace may affect the family. In a recent review, Perry-Jenkins et al (2000) reported that job stress and conflict are related to various aspects of distress, and these in turn are related to poorer marital relations, parent-child relations, and child outcomes. Crouter et al (1999) found that parents who described feeling more pressure at work also reported greater role overload, which was in turn associated with higher levels of conflict with adolescent children. Similarly, in examining intra-individual variability in experiences of work stress, Repetti and Wood (1997) found that mothers were more behaviorally and emotionally withdrawn on days when they reported greater workloads or interpersonal stress at work.

As discussed earlier, nonstandard hours are a crucial component of working in a hotel, and this job characteristic can interfere with family life. Using a national sample of 3,476 surveyed married couples working in a variety of industries, Presser (2000) found that working evening or night shifts or working rotating schedules and weekends 
significantly increased the likelihood of marriages ending in separation or divorce within five years. White and Keith (1990) also found that non-daytime hours of employment were related to higher levels of divorce. Perry-Jenkins, Goldberg, Pierce, and Haley (forthcoming) noted that when couples worked alternating shifts (versus working the same shift), both husbands and wives reported a pronounced decline in love for their spouse over the transition to parenthood. There is also some indication that nonstandard work hours are associated with problem behaviors and poor educational outcomes in the children of employees (Bogen and Joshi 2001; Heymann 2000).

Again, it must be emphasized that the effects of work on the family are not invariably negative. Employees' work lives can enhance aspects of their personal lives through providing opportunities and resources that improve personal and family life (Barnett 1996; Grzywacz and Marks 2000; Hammer, Cullen, Neal, Sinclair and Shafiro 2005). The hotel sector is rich in opportunities for managers' families to benefit from. As noted, despite negative and disruptive aspects, relocation also provides opportunities for families to live in and learn about different cultures. At a more pragmatic level, many hotel companies offer employees significant discounts or complimentary rooms at their properties, enabling employees and their families to take vacations that they might otherwise be unable to afford.

Work-family conflict has a negative relationship with marital quality and relationships with children. This article argues that these findings will hold true among hotel managers and that this association is likely to be particularly pronounced given the prevalence of nonstandard work hours and relocation. There are features of work in the hotel sector that enhance employees' and their families' personal lives. Thus, reports of facilitation will be positively related to reports of family satisfaction with the job.

Proposition 4a: Work-family conflict (and its antecedents) will be negatively related to marital quality and relationships with children.

Proposition 4b: Work-family facilitation will be positively related to family satisfaction with the job.

\section{Moderators}

Because these relationships do not occur in a vacuum, other factors that may alter them must be considered. First, individuals do not experience the world in the same way. Personality and background characteristics provide a lens through which people perceive and react to situations around them, including how they perceive and experience the work and family interface. The model presented in this article proposes that individual differences such as gender, age, positive/negative affectivity, and locus of control impact how hotel employees experience the work-life interface. There are also family-level factors that moderate the associations between the organizational factors and the various outcomes presented here, including the presence of a supportive spouse, presence of children, and family willingness to 
relocate, characteristics that may shape how individuals are impacted by the organization.

Individual Level. The heuristic framework addresses individual characteristics that may shape the association between an employee's work and family life, regardless of industry. Certain of these can be thought of as adding to or detracting from personal resources in coping with daily stresses (Grandey and Cropanzano 1999). For example, people with a more positive outlook on life may have a reserve of confidence that enables them to cope with difficult situations more adeptly than those with a more negative view.

Several background characteristics may influence an individual's work-family experience. Although Frone (2003) reports that males and females tend to report similar levels of conflict, previous research has indicated that gender is related to the experience of conflict (Duxbury and Higgins 1991; Gutek, Searle, and Klepa 1991). Specifically, some gender differences in specific factors contribute to conflict and to its specific consequences (Grzywacz and Marks 2000). For example, Duxbury and Higgins (1991) found that work involvement and family expectations were stronger predictors of perceptions of conflict for women than for men, largely because of societal expectations of women in the workplace and at home. In terms of individuals' satisfaction with various life roles, they found that women allowed the home role to interfere with their satisfaction at work, whereas men allowed work-role obligations to interfere with their satisfaction with the family role. Married women from across industries are more likely to report that family demands negatively impact their job performance (Keene and Reynolds 2005), in large part because women are more likely to adjust their workload for the sake of the family. In fact, women are nearly twice as likely as men to place reasonable limits on work life to protect the family from the negative consequences of work obligations (such as refusing jobs that require more travel, turning down jobs or promotions that require relocation, or putting in face time), perhaps due to differences in gender socialization (Duxbury and Higgins 1991; Valdez and Gutek 1987). The limitations that women, in particular, are more likely to put on work in order to protect the family could be particularly damaging for their careers in the hotel sector, where relocation and travel are a necessity for career advancement and face time is often a strong norm.

Age can also impact the way an individual experiences a situation. As individuals move through the life course, different domains of life take different precedence and different resources are available. For example, younger adults tend to experience more conflict than older adults (Grandey and Cropanzano 1999), as they are more likely to have young children. In addition, older people are more likely to have seniority and status at work, which in turn bring opportunities for flexibility and lessen the likelihood of work and work stress interfering with family life (Parasuraman, Greenhouse, and Granrose 1992).

Personality is a relatively new area of study in work-family research. Certain personality factors, such as positive or negative affectivity, 
either facilitate or hinder how well hotel employees cope with challenges and problems, both at work and at home (Frone 2003). In a survey of almost 2,000 employed Americans, Grzywacz and Marks (2000) found that high neuroticism, a construct very similar to negative affectivity, was associated with higher levels of work-family conflict, whereas the opposite was true for those high in positive affectivity. Wayne et al (2002) found similar results: traits such as openness to experience, extraversion, and agreeableness were positively associated with facilitation. Extraverts and individuals high in positive affectivity are more likely to evaluate situations in a positive way and more likely to see a work challenge as an opportunity, rather than a threat (Isen, Shalker, Clark and Karp 1978; Larsen and Ketelaar 1991).

Across professions, locus of control is a relatively well-established influence on how employees perceive their situations and whether or not they experience stress as a result. Individuals for whom control resides in external phenomena, such as a boss or chance, are more likely to experience higher levels of stress or job dissatisfaction in response to a difficult situation than those who perceive control to reside within themselves (Noor 2002; Spector, Cooper, and Aguilar-Vafaie 2002).

Individual differences play an important role in the relationship between work and family in that they shape how employees perceive and cope with various stressors. In particular, positive affectivity and an internal locus of control should act as resources for hotel managers to help buffer the effects of an un-family-friendly organizational culture. Additionally, differences such as age and gender will shape how managers react to the demands created by their jobs. Further, individual differences such as positive affectivity, extraversion, agreeableness, and openness to experience will allow hotel managers to capitalize on the opportunities and benefits that come with working in this business, strengthening relationships pertaining to facilitation.

Proposition 5a: Background characteristics (eg, being older), personality factors (eg, positive affectivity), and an internal locus of control will act as resources to buffer the potentially stressful effects of organizational context on work-family conflict and related outcomes.

Proposition 5b: Female hotel employees will be more likely than their male counterparts to turn down relocations and less likely to engage in face time.

Proposition 5c: Personality factors such as positive affectivity, extraversion, agreeableness, and openness to experience will act as resources to strengthen the associations pertaining to work-family facilitation.

Family Level. Family circumstances can also be thought of as either adding to or detracting from an individual's resources for navigating the work and family domains across industries (Grandey and Cropanzano 1999; Voydanoff 2002). The spouse plays a very important role in shaping an employee's experience of conflict (Frone 2003). A supportive one may provide direct assistance with demands at home so that the individual has less need to worry about them while at work. The spouse may also enable the employee to withdraw from family interaction in 
order to recover emotional equilibrium following stressful workdays (Repetti 1994). Family-related support also increases the likelihood that an employee will report that work life is enhanced by family life (Grzywacz and Marks 2000). Although a supportive spouse can be a valuable resource, children at home tend to be a major drain on an individual's time and energy and contribute significantly to conflict (Eagle, Miles, and Icenogle 1997; Grandey and Cropanzano 1999), especially for employees with young children (Fernandez 1986). Moreover, these associations tend to be stronger as the number of children in a family increases (Spector et al 2004).

Willingness to relocate is a family variable that is important to the hotel sector because of the frequency of relocation. Brett, Stroh, and Reilly (1993) surveyed 827 employees from 20 Fortune 500 companies, some of which were hotel companies, and concluded that a spouse's willingness to relocate was the single most important predictor of an employee's willingness to relocate. Job pressure to relocate, combined with a spouse who is unwilling to do so, can be a tremendous source of distress for a hotel manager. Brett and Reilly (1988) found that a spouse's willingness to relocate was associated with the employee's attitudes toward relocation, but it also depended on family size. The more children couples had, the less willing they were to relocate. The number of dual-earner families has risen steeply in recent years, meaning that it is now common for spouses to confront family-changing decisions about relocation that have implications for their partner's career. In a global industry, such as tourism, issues of spousal support for relocation take on even more complexity. As with individual differences, certain family characteristics, such as the presence of young children, may amplify the effects of work-family conflict on managers while others, such as a spouse that provides emotional and logistical support, may ameliorate it.

Proposition 6: A supportive spouse and family willingness to relocate will act as resources to buffer the negative effects of organizational context on work-family conflict and the related outcomes. Family size and the presence of young children will strengthen the negative associations proposed in this model.

\section{Reactions and Responses from the Organization}

Several hotel companies have implemented policies and programs to address work and family issues to gain a strategic advantage. Unfortunately, systematic research on the effectiveness of these policies has yet to be carried out. The evidence of their effectiveness is mostly anecdotal, but this preliminary evidence suggests promising results for these programs and policies. Enz and Siguaw (2000) reported that, among companies using human resources best practices, which included a number of family-friendly practices, employee satisfaction increased, there was a reduction in turnover, and productivity increased. The Day Hospitality Group, for example, adopted a program that required a 90-day sabbatical leave for general managers with five years at the company to emphasize the importance of a balanced life (Enz 
and Siguaw 2000). While empirical data were not yet available, the president of Day Hospitality maintained that this program will inspire general managers to return to work refreshed and replenished with a new, clearer frame of mind (Enz and Siguaw 2000). The MGM Grand and Casinos (Las Vegas) offer accredited onsite child-care centers for employees. These are open 24 hours a day, seven days a week (Children's Choice Learning Centers 2004).

Some hotel companies are experimenting with job-sharing. Sheraton has adopted it among sales managers. This flexibility allows these managers to handle changing work and family needs, has been cost effective, and has had positive outcomes for customers (Enz and Siguaw 2000). Ritz Carlton management decided to allow the front-office employees in one of their hotels to set their own work schedules as part of an effort to increase employee empowerment. Management reported that the project was successful, and the company decided to implement the program across the entire hotel chain (Enz and Siguaw 2000).

Rather than focusing solely on work-life policies, Marriott recently experimented with changing an important aspect of its culture in one of its geographic regions. Its management realized that the standard way of thinking about work in the company was, "the more hours you put in, the better" (Munck 2001:125). Marriott executives made several regional operational changes, such as eliminating certain previously required meetings. Most importantly, the company actively encouraged a change in attitude about the need for face time, and this was demonstrated even at the very top levels of management. It succeeded in reducing the average amount of time each manager was spending at work, thereby reducing the number of those who felt they were unable to take adequate care of their personal and family responsibilities, while at the same time maintaining a high quality of service to the guests and avoiding adverse impacts on financial performance.

Rigorous research in this area is a very important next step for hospitality and work-life studies. Specifically, researchers should investigate whether implementing work-family practices in the hotel sector does, indeed, lead to a more family-friendly culture and more reasonable norms regarding issues like long hours. Furthermore, they should also ask whether these types of programs lead to the expected longterm outcomes reported here (such as decreased turnover, increased performance). While researchers have not yet established concrete, rigorous findings, the preliminary evidence suggests that tying together family-friendly policies and practices into organizational strategy may help hotel companies gain strategic advantage through better recruitment, retention, and productivity of employees.

\section{CONCLUSION}

This article has provided an overview of many of the ways in which work, especially employment in the hotel sector and, by extension, in the entire tourism industry, can affect employees and their families and vice versa. Now is an opportune time for leaders to examine 
policies and practices surrounding the work and family interface as the lodging business has largely recovered from the impacts of September 11 th and is once again experiencing growth and profitability (O'Neill 2005). Managers and executives are seeking ways to attract and retain top talent, as well as reduce expenses, all while maintaining or improving guest service. As discussed earlier, addressing work-family issues has the potential to help achieve these objectives. Further, because only a few companies appear to have embraced family-friendly approaches to organizing work, strategists may wish to consider how these practices could be used to gain a competitive advantage both in hotel and other tourism enterprises, specifically through increased commitment, reduced absenteeism, reduced turnover, and superior productivity and performance (Dermody and Holloway 1998; Frone 2003; Frone et al 1997; Kossek and Ozeki 1999; Wayne et al 2002). Significantly, researchers may wish to consider the implications of these practices on employees in other related lines of work.

Several strategic implications of the work and family relationship arise in the model. First, based on the knowledge that individual factors, such as personality and locus of control, play a role in this relationship, hotel and other tourism companies may want to consider them when developing criteria for hiring new employees and budding managerial talent. Companies, tourism and otherwise, should consider the "friendliness" of their organizational culture for personal lives of employees and consider redesigning jobs to give them more flexibility. One best practice identified here is that of downplaying the need for face time when there is not an actual need to be physically present (Munck 2001). Similarly, when long and irregular hours are required as part of a job, employees should have some say in determining their schedule (Enz and Siguaw 2000). Another best practice is providing them with ample support when relocation is required (Martin 1999). While the hotel sector as a whole has several intrinsic characteristics that contribute to conflict, individual companies have latitude in the extent to which they emphasize these characteristics, or explore more innovative ways of coping with the unique demands of a $24 / 7$ service industry.

An organization's strategies should be developed subsequent to an internal audit that identifies the strengths of an organization (David 2001). When an organization achieves a match between internal strengths and external opportunities, a competitive advantage is achieved. In other words, addressing work-family issues could enhance a company's strategic advantage relative to their competitors in the marketplace, including increased organizational commitment, reduced absenteeism, reduced turnover, superior performance, and perhaps even reduced health care costs. For example, an organization that implements creative solutions regarding the type and volume of managerial hours and relocations may achieve a strategic advantage with respect to attracting and retaining competent and productive managers, and reduce the likelihood of them leaving the company or the sector altogether.

Finally, this framework has implications for the way that the tourism industry views the outcomes of the work and family relationship. 
Rather than viewing family-friendly practices as a liability, companies should recognize that these practices have potential strategic advantages for them with regards to job performance and major industry problems such as turnover. This is one of the most pervasive problems in the hotel sector-the annual rate for management positions is estimated to be 21\% (Smith Travel Research 2003). Over ten years ago, Hogan (1992) estimated that the cost of an individual case of management turnover in the hospitality sector was as high as $\$ 17,000$ to $\$ 20,000$ in recruitment and training costs, amounts that would be significantly higher today. Marriott suggests that each $1 \%$ increase in its employee turnover rate cost the company between $\$ 5$ and $\$ 15$ million in lost revenues (Schlesinger and Heskett 1991). Given these estimates, combined with the evidence that work-family concerns are a major factor in the sector, turnover due to work-family issues is likely to be very costly. Raising commitment and retention through effective use of work-family policies could be an important way in which hotel companies and other tourism organizations gain a strategic advantage over their competitors.

A few companies have begun to use innovative human resource practices to address work-life issues. So far, these practices appear to be helping employees deal with their work-family needs, as well as enhancing employee satisfaction, turnover, and guest satisfaction. That said, rigorous research on work-life issues in the sector, and tourism as a whole, is scarce. There is much to be done to investigate the work-life needs of this industry and to evaluate the effectiveness of the practices being implemented. More and better investigation in this area could help hotel companies, as well as other tourism sectors, examine the return on investment of their current practices, as well as evaluate some of the cutting-edge practices that have been introduced recently. Furthermore, this research theme could help inform the broader worklife literature on addressing conflict in service industry jobs. A

Acknowledgements - The authors thank the Center for Work and Family Research at the Pennsylvania State University for sponsoring this research.

\section{REFERENCES}

Allen, T., and J. Russell

1999 Parental Leave of Absence: Some not so Family-friendly Implications. Journal of Applied Social Psychology 29:166-191.

Aryee, S.

1992 Antecedents and Outcomes of Work-Family Conflict Among Married Professional Women: Evidence from Singapore. Human Relations 45:813-837. Barnett, R.

1996 Toward a Review of the Work/Family Literature: Work in Progress. Boston: Wellesley College Center for Research on Women.

Bogen, K., and P. Joshi

2001 November Bad Work or Good Move: The Relationship of Part-time and Non-standard Work Schedules to Parenting and Child Behavior in Working Poor Families. Paper presented at the conference on "Working Poor Families: Coping as Parents and Workers". 
Brett, J.

1982 Job Transfer and Well-being. Journal of Applied Psychology 67:450-463.

Brett, J., and A. Reilly

1988 On the Road Again: Predicting the Job Transfer Decision. Journal of Applied Psychology 73:614-620.

Brett, J., L. Stroh, and A. Reilly

1993 Pulling Up Roots in the 1990s: Who's Willing to Relocate? Journal of Organizational Behavior 14:49-60.

Children's Choice Learning Centers

2004 Children's Choice Learning Centers at MGM Accredited by NAEYC $<$ http://www.childrenschoice.com/cclc/press_release_naeyc.html>.

Cooper, M., M. Frone, M. Russell, and P. Mudar

1995 Drinking to Regulate Positive and Negative Emotions: A Motivational Model of Alcohol Use. Journal of Personality and Social Psychology 69:990-1005.

Corsun, D., and C. Young

1998 An Occupational Hazard: Alcohol Consumption among Hospitality Managers. Marriage and Family Review 28:187-211.

Crouter, A.

1984a Participative Work as an Influence on Human Development. Journal of Applied Developmental Psychology 5:71-90.

1984b Spillover from Family to Work: The Neglected Side of the Work-family Interface. Human Relations 37:425-442.

Crouter, A., M. Bumpus, M. Maguire, and S. McHale

1999 Linking Parents' Work Pressure and Adolescents' Well-being: Insights into

Dynamics in Dual-earner Families. Developmental Psychology 35:1453-1461.

David, F.

2001 Strategic Management Concepts. Upper Saddle River: Prentice Hall.

Deery, M., and R. Shaw

1997 An Exploratory Analysis of Turnover Culture in the Hotel Industry in Australia. International Journal of Hospitality Management 16:375-392.

Dermody, M., and R. Holloway

1998 Recruitment and Retention of Managers. Cornell Hotel and Restaurant Administration Quarterly 39(6):20-25.

Duxbury, L., and C. Higgins

1991 Gender Differences in Work-family Conflict. Journal of Applied Psychology 76:60-74.

Eagle, B., E. Miles, and M. Icenogle

1997 Interrole Conflicts and the Permeability of Work and Family Domains: Are

There Gender Differences? Journal of Vocational Behavior 50:168-183.

Eby, L., and T. Allen

1998 Perceptions of Relocation Services in Relocation Decision-Making: An Exploratory Field Study. Group and Organization Management 23:447-469.

Eder, R., and C. Lundberg

1990 "Paying Your Dues" in the Hospitality Industry: How Functional is the Belief? Hospitality Research Journal 14:363-369.

Enz, C., and J. Siguaw

2000 Best Practices in Human Resources. Cornell Hotel and Restaurant Quarterly 41:48-61.

Fernandez, J.

1986 Child Care and Corporate Productivity: Resolving Family/Work Conflicts. Lexington: Lexington Books.

Frankel, M.

1998 Creating the Family Friendly Workplace: Barriers and Solutions. In Handbook of Organizational Health Psychology: Programs to Make the Workplace Healthier, S. Klarreich, ed., pp. 79-100. Madison: Psychosocial Press.

Frone, M.

2003 Work-family Balance. In Handbook of Occupational Health Psychology, J. Quick and L. Tetrick, eds., pp. 143-162. Washington DC: American Psychological Association. 
Frone, M., M. Russell, and G. Barnes

1996 Work-family Conflict, Gender, and Health-related Outcomes: A Study of Employed Parents in two Communities. Journal of Occupational Health Psychology 1:57-69.

Frone, M., J. Yardley, and K. Markel

1997 Developing and Testing an Integrative Model of the Work-family Interface. Journal of Vocational Behavior 50:145-167.

Galinsky, E., J. Bond, and D. Friedman

1996 The Role of Employers in Addressing the Needs of Employed Parents. Journal of Social Issues 52:111-136.

Grandey, A., and R. Cropanzano

1999 The Conservation of Resources Model Applied to Work-family Conflict and Strain. Journal of Vocational Behavior 54:350-370.

Greenglass, E., and R. Burke

1988 Work and Family Precursors of Burnout in Teachers: Sex Differences. Sex Roles 18:215-229.

Greenhaus, J., and N. Beutell

1985 Sources of Conflict between Work and Family Roles. Academy of Management Review 10:76-88.

Greenhaus, J., S. Parasuraman, and K. Collins

2001 Career Involvement and Family Involvement as Moderators of Relationships between Work-family Conflict and Withdrawal from a Profession. Journal of Occupational Health Psychology 6:91-100.

Grzywacz, J., and N. Marks

2000 Reconceptualizing the Work-family Interface: An Ecological Perspective on the Correlates of Positive and Negative Spillover between Work and Family. Journal of Occupational Health Psychology 5:111-126.

Gutek, B., S. Searle, and L. Klepa

1991 Rational versus Gender Role Explanations for Work-family Conflict. Journal of Applied Psychology 76:560-568.

Hammer, L., J. Gullen, M. Neal, R. Sinclair, and M. Shafiro

2005 The Longitudinal Effects of Work-family Conflict and Positive Spillover: Depressive Symptoms among Dual-earner Couples. Journal of Occupational Health Psychology 10:138-154.

Harris Mulvaney, R., and A. Grandey

2004 Off the Job Training: A New Model of Non-work to Work Facilitation. Paper presented at the 19th annual conference for the Society for Industrial and Organizational Psychology, Chicago.

Heymann, J.

2000 The Widening Gap: Why America's Working Families are in Jeopardyand what can be done about it. New York, NY: Basic Books.

Hogan, J.

1992 Turnover and What to Do About It. Cornell Hotel and Restaurant Quarterly 33:40-45.

Hulin, C.

1991 Adaptation, Persistence and Commitment in Organizations. In Handbook of Industrial and Organizational Psychology (vol. 2) M. Dunnette and L. Hough eds., pp. 445-506. Palo Alto: Consulting Psychologists Press.

Isen, A., T. Shalker, M. Clark, and L. Karp

1978 Affect, Accessibility of Material in Memory and Behavior: A Cognitive Loop? Journal of Personality and Social Psychology 36:1-12.

Judiesch, M., and K. Lyness

1999 Left behind? The Impact of Leaves of Absence on Managers' Career Success. Academy of Management Journal 42:641-651.

Keene, J., and J. Reynolds

2005 The Job Costs of Family Demands. Journal of Family Issues 26:275299.

Kennedy, D., and M. Fulford

1999 On the move: Management Relocation in the Hospitality Industry. Cornell Hotel and Restaurant Administration Quarterly 40(2):60-68. 
Kirchmeyer, C., and A. Cohen

1999 Different Strategies for Managing the Work/Non-work Interface: A Test

for Unique Pathways to Outcomes. Work and Stress 13:59-73.

Kossek, E., and C. Ozeki

1998 Work-family Conflict, Policies, and the Job-Life Satisfaction Relationship: A Review and Directions for Organizational Behavior-Human Resources Research. Journal of Applied Psychology 83:139-149.

1999 Bridging the Work-family Policy and Productivity Gap: A Literature Review. Community, Work, and Family 2:7-32.

Lambert, $\mathrm{S}$.

1990 Processes Linking Work and Family: A Critical Review and Research Agenda. Human Relations 43:239-257.

Larsen, R., and T. Ketelaar

1991 Personality and Susceptibility to Positive and Negative Emotional States. Journal of Personality and Social Psychology 61:132-140.

Leiter, M., and M. Durup

1996 Work, Home, and In-between: A Longitudinal Study of Spillover. Journal of Applied Behavioral Science 32:29-47.

Lu, L., and C. Cooper

1990 Stress of Job Relocation: Progress and Prospect. Work and Stress $4: 121-128$.

Martin, R.

1999 Adjusting to Job Relocation: Relocation Preparation Can Reduce Relocation Stress. Journal of Occupational and Organizational Psychology 72:231-235.

Mathieu, J., and D. Zajac

1990 A Review and Meta-Analysis of the Antecedents, Correlates, and Consequences of Organizational Commitment. Psychological Bulletin 108:171-194.

Milliken, F., L. Martins, and H. Morgan

1998 Explaining Organizational Responsiveness to Work-family Issues: The Role of Human Resource Executives as Issue Interpreters. Academy of Management Journal 41:580-592.

Mowday, R., L. Porter, and R. Steers

1982 Employee-Organizational Linkages: The Psychology of Commitment, Absenteeism, and Turnover. In Organizational and Occupational Psychology, P. Warr, ed., pp. 219-229. New York: Academic Press.

Munck, B. 2001 Changing a Culture of Face Time. Harvard Business Review 79:125-131.

Munton, A. 1992 Psychological Well-being Following a Job Transfer: Predicting Change amongst Employees and Families. Unpublished manuscript, Social and Applied Psychology Unit, University of Sheffield.

Netemeyer, R., J. Maxham, and C. Pullig 2005 Conflicts in the Work-family Interface: Links to Job Stress, Customer Service Employee Performance, and Customer Purchase Intent. Journal of Marketing 69:130-143.

Noor, N. M.

2002 Work Family Conflict, Locus of Control, and Women's Well-Being: Tests of Alternative Pathways. Journal of Social Psychology 142(5):645-662.

O'Neill, J. 2005 Up the Value Roller Coaster. Lodging Hospitality 61:32.

Parasuraman, S., J. Greenhaus, and C. Granrose 1992 Role Stressors, Social Support, and Well-Being among Two-Career Couples. Journal of Organizational Behavior 13:339-356.

Perry-Jenkins, M., A. Goldberg, C. Pierce, and H. Haley

forthcoming Employment Schedules and the Transition to Parenthood: Implications for Mental Health and Marriage.

Perry-Jenkins, M., R. Repetti, and A. Crouter

2000 Work and Family in the 1990s. Journal of Marriage and the Family 62:981-998. 
Presser, H.

2000 Nonstandard Work Schedules and Marital Instability. Journal of Marriage and the Family 62:93-110.

2004 Employment in a 24/7 Economy: Challenges for the Family. In WorkFamily Challenges for Low-Income Parents and Their Children, A. Crouter and A. Booth, eds., pp. 83-106. Mahwah: Lawrence Erlbaum.

Repetti, R.

1994 Short Term and Long-term Processes Linking Job Stressors to Father-Child Interaction. Social Development 3:1-15.

Repetti, R., and J. Wood

1997 Effects of Daily Stress at Work on Mothers' Interactions with Preschoolers. Journal of Family Psychology 11:90-108.

Ruderman, M., P. Ohlott, K. Panzer, and S. King

2002 Benefits of Multiple Roles for Managerial Women. Academy of Management Journal 45:369-386.

Schlesinger, L., and J. Heskett

1991 The Service-Driven Company. Harvard Business Review 69:71-81.

Smith Travel Research

2003 March Smith Travel Research Announces Full Year 2002 U.S. Lodging Industry Results <www.smithtravelresearch.com $>$.

Spector, P. E., C. L. Cooper, and M. E. Aguilar-Vafaie

2002 A Comparative Study of Perceived Job Stressor Sources and Job Strain in American and Iranian Managers. Applied Psychology: An International Review 51:446-457.

Spector, P., C. Cooper, S. Poelmans, T. Allen, M. O’Driscoll, J. Sánchez, O. Siu, P. Dewe, P. Hart, L. Lu, L. Renault de Moraes, G. Ostrognay, K. Sparks, P. Wong, and $\mathrm{S}$. Yu

2004 A Cross-National Comparative Study of Work/Family Stressors, Working Hours, and Well-Being: China and Latin America vs. the Anglo World. Personnel Psychology 57(1):119-143.

Spinelli, M., and G. Canavos

2000 Investigating the Relationship between Employee Satisfaction and Guest Satisfaction. Cornell Hotel and Restaurant Administration Quarterly 41(6):29-33.

Stalcup, L., and T. Pearson

2001 A Model of the Causes of Management Turnover in Hotels. Journal of Hospitality and Tourism Research 25:17-30.

Thomas, L., and D. Ganster

1995 Impact of Family-Supportive Work Variables on Work-family Conflict and Strain: A Control Perspective. Journal of Applied Psychology 80:6-15.

Thompson, C., L. Beauvais, and K. Lyness

1999 When Work-family Benefits are not Enough: The Influence of WorkFamily Culture on Benefit Utilization, Organizational Attachment, and WorkFamily Conflict. Journal of Vocational Behavior 54:392-415.

Thompson, C., C. Thomas, and M. Maier

1992 Work-family Conflict and the Bottom Line: Reassessing Corporate Policies and Initiatives. In Woman-Power: Managing in Times of Demographic Turbulence, U. Sekaran and F. Leong, eds., pp. 59-84. Newbury Park: Sage.

Thompson, G.

1998 Labor Scheduling. Cornell Hotel and Restaurant Administration Quarterly $39(5): 22-31$.

Valdez, F., and B. Gutek

1987 Family Roles: A Help or Hindrance for Working Women. In Women's Career Development, B. Gutek and L. Larwood, eds., pp. 157-169. Beverly Hills: Sage.

Voydanoff, P.

2002 Linkages between the Work-family Interface and Work, Family, and Individual Outcomes. Journal of Family Issues 23:138-164. 
Wayne, J., N. Musisca, and W. Fleeson

2002 Relationships of the Big Five to Work-family Conflict and Facilitation. Poster presented at the 17th annual conference for the Society of Industrial/ Organizational Psychology, Toronto.

White, L., and B. Keith

1990 The Effect of Shift Work on the Quality and Stability of Marital Relations. Journal of Marriage and the Family 52:453-462.

Submitted 13 October 2003. Resubmitted 18 June 2004. Resubmitted 24 February 2006. Final version 1 May 2006. Accepted 9 June 2006. Refereed anonymously. Coordinating Editor: David A. Dittman

Available online at www.sciencedirect.com

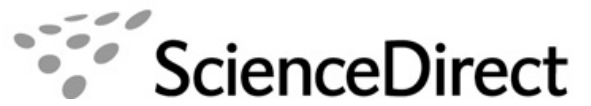

